\title{
Detection of intraocular leptospiral DNA, antibodies and Leptospira spp. in horses with equine recurrent uveitis in different laboratories
}

\author{
Eva I. A. Baakel, Myriam von Borstel', Karl Rohn² and Bernhard Ohnesorge \\ 1 Clinic for Horses, Universitiy of Veterinary Medicine Hannover, Foundation, Hannover, Germany \\ 2 Institute for Veterinary Biometry and Epidemiology, University of Veterinary Medicine Hannover, Foundation, Hannover, Germany
}

\begin{abstract}
Summary: Equine recurrent uveitis (ERU) is an ocular disease characterized mainly by recurrent episodes of inflammation, alternating with quiescent episodes of various durations. There are numerous aetiological theories for the cause of ERU, but to date, the "classic ERU" is most commonly associated with an intraocular leptospiral infection. The pars plana vitrectomy has, so far, been the most promising treatment of ERU and is thought to be more successful in eyes with detectable leptospiral antibodies in the microscopic agglutination test (MAT) and therefore a preselection is recommended. The objective of this study was to investigate whether different laboratories have an influence on the frequency of detection of leptospiral DNA and leptospiral antibodies from vitreal samples of horses with ERU and if these results are in accordance with cultural testing of the vitreal samples. Vitreal samples were obtained from 93 eyes of 78 horses of various breeds and age with a clinical history of ERU. The vitreal samples were taken at the beginning of the vitrectomy to keep the dilution of the vitreal samples as low as possible. The samples were split and sent to three different laboratories in Germany (L1, L2 and L3). Laboratory 1 (L1) performed a polymerase chain reaction (PCR) and a MAT, laboratory 2 (L2) carried out a PCR and laboratory 3 (L3) performed a MAT, a cultural examination and an enzyme-linked immunosorbent assay on the vitreal specimens. The amount of dilution was evaluated by comparing the urea content of 34 vitreal samples with the urea content of the serum of each of the horses at the time of sampling. Furthermore, a serial dilution was performed with undiluted vitreal material of two enucleated eyes and sent to L1 for MAT and PCR. The results of the PCR indicated a strong conformity between L1 and L2 (Kappa 0.95), both laboratories concurrently revealed 52 positive and 31 negative results and only two specimens showed deviating results. The MAT in L1 was positive in $51 \%$ of the vitreal samples tested, whereas only $41 \%$ of the vitreal samples were tested positive in L3. The conformity was, moreover, serovar- and breed-dependent. The Kappa was 0.67 when only including serovar Grippotyphosa, and was 0.82 for serovar Pomona (Tab. 5). Warmblood horses displayed a Kappa of 0.56 between L1 and L3, whereas the Kappa for the Icelandic horses was 0.91 between L1 and L3. The cultivation of leptospires was successful in 16\% of the vitreal specimens. The dilution of vitreal samples was measured to range between 1 and 2.1 with a standard deviation of 1.68. Overall, 67 vitreal samples were tested simultaneously in all three laboratories. A positive result in at least one of the tests performed occurred in $57 \%$ (38), whereas $43 \%$ (29) of the vitreal specimens were tested negative in all five tests performed (PCR in L1 and L2, MAT in L1 and L3, and culture in L3). The variation of agreement of the MAT between serovar Grippotyphosa and serovar Pomona and between Warmblood and Icelandic horses in L1 and L3 might be accounted for by the utilisation of congeneric, but different strains from the same leptospiral serotype. The dilution of vitreal specimens at the beginning of the vitrectomy might have influenced the results of this study. However, the serial dilution showed a negligible influence of a dilution as high as $1: 3$. The strong conformity of the results for PCR between L1 and L2 indicate a similar sensitivity of both PCR protocols. Results indicated a strong inter-laboratory agreement when PCR was used for the detection of leptospiral DNA, whereas the MAT showed a variance of results that needs to be carefully regarded for interpretation. Therefore, basing a decision against a pars plana vitrectomy only upon a negative MAT result of anterior chamber fluid from a single laboratory could not be recommended.
\end{abstract}

Keywords : Leptospires, ERU, Uveitis, PCR, MAT 7, Ophthalmology

Citation: Nordemann E. I. A., von Borstel M., Rohn K., Ohnesorge B. (2016) Detection of intraocular leptospiral DNA, antibodies and Leptospira spp. in horses with equine recurrent uveitis in different laboratories. Pferdeheilkunde 32, 346-356

Correspondence: Prof. Bernhard Ohnesorge, Tierärztliche Hochschule hannover Foundation, Clinic for Horses, Bünteweg 9, 30669 Hannover, bernhard.ohnesorge@tiho-hannover.de

\section{Introduction}

Equine recurrent uveitis (ERU) is an ocular disease characterized mainly by recurrent episodes of inflammation, alternating with quiescent episodes of various durations. The disease is divided into different clinical subtypes. One classification differentiated between the "classic ERU", the "insidious ERU" and the "posterior ERU". The "classic ERU" was defined as acute and painful episodes of ocular inflammation affecting posterior and anterior parts of the eye, with recurrence after non-inflammatory or almost non-inflammatory episodes. The "insidious ERU" was instead characterized as a mild and almost painless inflammation of ocular structures, regularly seen in the Appaloosa and draught breed horses in the USA.
The "posterior Uveitis" was defined as an inflammation primarily affecting the vitreous body, choroid and retina, mostly present in Warmblood and draught breed horses, and horses imported from Europe to the USA (Gilger 2010). Other authors referred to the anatomic sites which were mainly affected during inflammation to divide ERU into different subgroups. They categorized ERU into a painful "anterior uveitis/iritis", an almost painless "intermediate uveitis/cyclitis/pars planitis" and a "posterior uveitis/choroiditis" or rather "panuveitis", because not only the choroid, but also the ciliary body is usually involved during inflammation (Spiess 2010, Tömördy et al. 2010, Wollanke et al. 2009). There are numerous aetiological theories for the causes of ERU, but to date, the "classic ERU" is most commonly associated with an 
intraocular leptospiral infection (Alexander 1990, Brandes et al. 2007, Brem et al. 1998, and 1999; Faber et al. 2000, Frellstedt 2009, Gerding et al. 2015, Gilger et al. 2008, Halliwell 1985, Heusser 1948, Niedermaier et al. 2006, Pearce et al. 2007, Polle et al. 2014, Rimpau 1947, Schwink et al. 1989, Sillerud et al. 1987, von Borstel et al. 2010, Wiehen 2012, Wollanke et al. 1998, Wollanke et al. 2004, Wollanke et al. 2000, Wollanke et al. 2001). Involvement of Leptospira spp. in the aetiology of ERU is substantiated by research groups through different analysing methods performed on vitreal or aqueous samples of horses with a clinical history of ERU. Leptospiral antibodies can be detected by the microscopic agglutination test (MAT) or the enzyme-linked immunosorbent assay (ELISA). The polymerase chain reaction (PCR) identifies leptospiral DNA and culturing of intraocular material can detect living leptospires. Positive results in the literature vary between 43 and $94 \%$ when performing the MAT on the vitreal material of affected eyes (Brandes et al. 2007, Brem et al. 1999, Gerding et al. 2015, Gilger et al. 2008, Polle et al. 2014, von Borstel et al. 2010, Wollanke et al. 1998, Wollanke et al. 2001). The PCR is able to detect leptospiral DNA in 40 to $100 \%$ of the eyes tested in the literature (Brandes et al. 2007, Faber et al. 2000, Polle et al. 2014, von Borstel et al. 2010). The rate for successful leptospiral culturing ranges between 21 and 53\% (Brandes et al. 2007, Brem et al. 1999, Faber et al. 2000, Hartskeerl et al. 2004, Wollanke et al. 2004, Wollanke et al. 2001). Therefore, a variation of the detection rate for intraocular leptospiral DNA, antibodies and living leptospires from affected eyes cannot be neglected. That is why it seems appropriate that the leptospiral involvement in ERU subdivides the different clinical forms of the disease described above into a "leptospiral-positive" and a "leptospiral-negative" form of ERU, instead of being the only reasonable aetiology for ERU. Other aetiological factors, such as genetic predispositions (Angelos et al. 1988, Dwyer et al. 1995, Fritz et al. 2014, Gilger 2010, Kulbrock et al. 2013), autoimmune components (Deeg 2008, and 2009, Deeg et al. 2002, Regan et al. 2012) and other pathogens, e.g. Onchocerca spp. (Böhm et al. 1954, Cello 1971, Roberts 1962, Schmidt et al. 1982) and Borrelia burgdorferi (Priest et al. 2012), are discussed in the literature, leading to a potentially multifactorial pathogenesis in some cases of ERU.
The most promising treatment of ERU is pars plana vitrectomy (Werry et al. 1992), with success rates for non-recurrence of uveitis between 73.6 and $100 \%$ (Frühauf 1998, Tömördy et al. 2010, von Borstel et al. 2005, Werry H. et al. 1992, Winterberg 1997). Tömördy et al. (Tömördy et al. 2010) suggested a better outcome for horses with intraocular antibodies against leptospires which were detectable by the MAT. They recommended performing a paracentesis of the anterior chamber prior to the vitrectomy, to select for eyes with detectable intraocular leptospiral antibodies. Since the MAT of the anterior chamber fluid would have a tremendous influence on the decision for or against the pars plana vitrectomy, it is essential to validate how reliable and comparable these laboratory results are.

The objective of this study was to investigate whether different laboratories have an influence on the frequency of detection of leptospiral DNA and leptospiral antibodies from vitreal samples of horses with ERU, and if these results are in accordance with the cultural testing of the samples.

\section{Materials and Methods}

A vitrectomy was carried out on 93 eyes of 78 horses with a clinical history of at least two acute and painful episodes of ocular inflammation, alternating with quiescent episodes of various durations. All eyes, therefore, met the criteria for the "classic ERU". The patient population was almost entirely resident in northern Germany and was composed of different breeds with a mean age of 8.1 years $(4.5-23.4$ years) (Tab. 1).

Vitreous samples were taken in the first few seconds of the vitrectomy to keep the dilution of the vitreal body as low as possible. The vitreous body was flushed with up to $500 \mathrm{ml}$ of BSS PLUS ${ }^{\circledR 1}$, charged with gentamicin ${ }^{2}(160 \mu \mathrm{g} / \mathrm{ml})$. Vitreous material was transferred from the specimen collection vial of the vitrectomy system ${ }^{3}$ to sterile specimen cups. Vitreal samples were then evenly split into additional sterile specimen cups and sent to three different laboratories in Germany (L1, L2 and L3). Each sample was tested in the different laboratories for leptospiral antigen, leptospiral antibodies and the bacterium Leptospira spp. itself.

Tab. 1 Breed, number of vitrectomized horses, vitrectomized eyes, mean age in years with the minimum and maximum and gender of the horses. I Rasse, Anzahl vitrektomierter Pferde, Anzahl vitrektomierter Augen, mittleres Alter und Geschlecht der Pferde.

\begin{tabular}{|c|c|c|c|c|c|}
\hline Breed & Horses & Vitreal samples & Mean age [years] & \multicolumn{2}{|c|}{ Gender } \\
\hline Warmblood horses & 46 & 54 & $7.4(2.1-16.7)$ & $\begin{array}{l}21 \\
23 \\
2\end{array}$ & $\begin{array}{l}\text { mares } \\
\text { geldings } \\
\text { stallions }\end{array}$ \\
\hline Icelandic horses & 16 & 21 & $5.2(1.8-19.9)$ & $\begin{array}{l}7 \\
7 \\
2\end{array}$ & $\begin{array}{l}\text { mares } \\
\text { geldings } \\
\text { stallions }\end{array}$ \\
\hline Ponies & 6 & 7 & $11(5-23.4)$ & $\begin{array}{l}2 \\
3 \\
1\end{array}$ & $\begin{array}{l}\text { mares } \\
\text { geldings } \\
\text { stallions }\end{array}$ \\
\hline Frisian horses & 4 & 5 & $6.8(3.6-9.3)$ & $\begin{array}{l}1 \\
3\end{array}$ & $\begin{array}{l}\text { mares } \\
\text { geldings }\end{array}$ \\
\hline Quarter horses & 2 & 2 & 5 and 7 & 2 & geldings \\
\hline Other & 4 & 4 & $13.5(4.3-16.9)$ & $\begin{array}{l}3 \\
1\end{array}$ & $\begin{array}{l}\text { mares } \\
\text { stallions }\end{array}$ \\
\hline
\end{tabular}


A PCR was carried out on 85 vitreal samples in L1 and L2. The PCR performed by L1 was a nested PCR targeting the leptospiral lipL32 gene. Whereas the PCR carried out by L2 was a real-time PCR, using TaqMan probes and targeting the leptospiral gltA gene.

Screening for leptospiral antibodies in vitreal samples was performed using a MAT on 88 vitreal samples by L1 and L3. During the MAT, different strains of live leptospires were added to serial dilutions of the sample material. The endpoint dilution was analysed by dark field microscopy, and defined as the dilution with $50 \%$ agglutination of the leptospiral bacteria administered with potential intravitreal antibodies (OiE 2014). The total number of live leptospiral serovars used was eleven for L 1 and nine for L3, while six serovars were tested simultaneously by both laboratories (Tab. 2). Specimens were regarded as positive if the endpoint dilution for at least one leptospiral serovar reached 1:100 or higher (OiE 2014). Moreover, L3 screened 74 serous samples for leptospiral antibodies by MAT.

A cultural examination was carried out on 75 vitreal samples in L3. These samples were embedded in bovine albumin tween transport medium, provided by the laboratory itself, immediately after they were obtained during vitrectomy and sent without cooling.

Furthermore, L3 conducted an enzyme-linked immunosorbent assay (ELISA) on 83 vitreal samples. The vitreal ELISA tested for leptospiral $\lg M, \lg G$ and $\lg A$ antibodies. Possible results were: negative, marginal, weak positive, positive and strong positive. A specimen was considered to be positive if at least one antibody reached a positive or very strong positive result. In order to evaluate the approximate amount of dilution, 34 of the vitreal samples and a plasma or serum sample from each of the 34 horses were taken during the vitrectomy and measured for the urea content. In order to further determine the impact of sample-dilution on the different methods, two enucleated eyes with a history of ERU were available to obtain undiluted vitreal material to perform a serial dilution. Three specimens with different dilutions were prepared. The first specimen was about $2 \mathrm{ml}$ of undiluted vitreal material, the second was $1 \mathrm{ml}$ of undiluted vitreal material mixed with $1 \mathrm{ml}$ of the flushing solution used during the vitrectomy ${ }^{4}$, and the third specimen was $1 \mathrm{ml}$ of undiluted vitreal material mixed with $3 \mathrm{ml}$ of the flushing solutionD. These specimens were sent to $L 1$ for PCR and MAT analysis.

Descriptive statistics were used to summarize the results for PCR, MAT and the cultural examination for each laboratory. Agreement between the different laboratories was assessed by using the kappa statistic (Landis et al. 1977) with 95\% confidence intervals $(\mathrm{Cl})$. The calculations were performed with SAS Enterprise Guide 7.1 (SAS Institute Inc., Cary, NC, USA). A kappa of 0.41-0.60 was interpreted as a moderate agreement, a kappa of $0.61-0.80$ as a substantial agreement and a kappa of 0.81-1.00 was interpreted as an almost perfect agreement (Landis et al. 1977). Quantitative conformity of leptospiral titres from L1 and L2 was illustrated by bubble charts (Fig. 1). Additionally, results were stratified for breed,

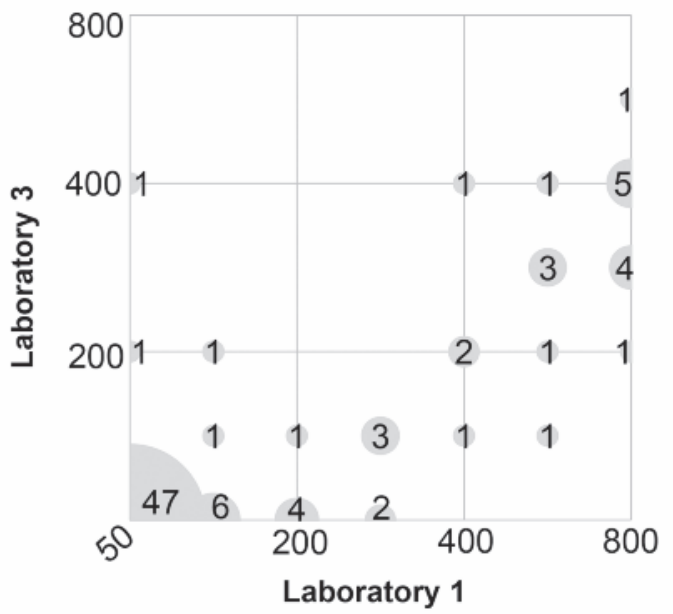

Fig. 1 Reciprocal titres for serovar Grippotyphosa measured in laboratory 1 (L1) and laboratory 3 (L3), compared in a bubble plot diagram. | Blasendiagramm zum Vergleich der reziproken Antikörpertiter des Serovars Grippotyphosa gemessen in Labor 1 (LI) und Labor 3 (L3).

Tab. 2 Leptospiral serovars tested in laboratory 1 (L1) and laboratory 3 (L3). | Leptospirenserovare, auf die nur im Labor 1 (L 1 ), nur im Labor 3 (L3) und in beiden Laboren getestet wurde.

\begin{tabular}{ccc}
\hline Leptospiral serovars & & \\
\hline L1 only & L1 and L3 & L3 only \\
\hline Australis & Bratislava & Javanica \\
Autumnalis & Canicola & Pyrogenes \\
Copenhageni & Grippotyphosa & Syxkoebing \\
Sejroe & Icterohaemorrhagiae & \\
Tarassovi & Pomona & \\
& Hardio & \\
\hline
\end{tabular}

Tab. 3 Overall results of laboratory 1 (L1), laboratory 2 (L2) and laboratory 3 (L3), and in comparison to each other. | Zusammengefasste und vergleichende Ergebnisse des Labor 1 (L1), Labor 2 (L2) und Labor 3 (L3).

\begin{tabular}{ccccc}
\hline Laboratory & Test & $\mathrm{n}$ & At least one positive result & All results positive \\
\hline $\mathrm{L} 1+\mathrm{L} 2+\mathrm{L} 3$ & PCR + MAT + Culture & 67 & $57 \%(38)$ & $9 \%(6)$ \\
L1 & PCR + MAT & 89 & $54 \%(48)$ & $34 \%(30)$ \\
L2 & PCR & 86 & $38 \%(33)$ & $38 \%(33)$ \\
L3 & MAT + Culture & 72 & $44 \%(32)$ & $13 \%(9)$ \\
\hline
\end{tabular}


and the MAT results were stratified for the leptospiral serovar detected.

\section{Results}

Detection of leptospiral DNA with PCR in L1 and L2 was performed concurrently on 85 vitreal samples. Identical findings from both laboratories were obtained for $98 \%$ (52 positive and 31 negative) of the samples tested. Only two specimens $(2 \%)$ showed contradictory results in both laboratories, i.e. the results of one specimen was positive in L 1 and negative in $L 2$, whereas the results of the other specimen was negative in L1 and positive in L2. Statistical analysis revealed a Kappa of 0.95 with a $95 \%$ confidence interval between 0.88 and 1.00 (Tab. 4a). Distinguishing the two main breeds from each other (Warmblood and Icelandic horses), the Kappa for Warmblood horses was 1.00 (95\% Cl 1.00-1.00) and the Kappa for Icelandic horses was 0.89 (95\% Cl 0.68-1.00).

A total of 88 vitreal specimens were tested concurrently via MAT in L1 and L3. In L1, the MAT was positive in 51\% (45) of the samples, whereas only $41 \%$ (36) of the samples tested positive in L3 (Tab. 3). A Kappa of 0.71 was calculated, including all serovars, comparing the MAT from L1 and L3 (Tab.
5). The Kappa was 0.67 when only serovar Grippotyphosa was included, and was 0.82 for serovar Pomona (Tab. 5). Warmblood horses displayed a Kappa of 0.56 between L1 and L3, whereas the Kappa for the Icelandic horses was 0.91 between L1 and L3 (Tab. 4b).

Due to a lack of laboratories able to perform a cultivation of leptospires from vitreal material in Germany, only L3 performed a cultural examination of the samples. Cultivation was performed on a total of 75 vitreal samples, and isolation of live leptospires was possible in 12 of these samples (16\%). An ELISA was carried out on 83 vitreal samples. At least one antibody reached a positive or very strong positive result in 44 of these samples (53\%), while no antibody reached a positive result in 39 vitreal samples (47\%).

Overall, pooling the results for all tests performed (PCR in L1 and L2, MAT in L1 and L3 and cultivation in L3), 67 samples were simultaneously sent to all three laboratories. In $43 \%$ (29) of the eyes, all five tests performed revealed a negative result, whereas at least one positive test result was found in $57 \%$ (38) of the vitreal specimens (Tab. 3).

A total of 89 vitreal specimens were tested concurrently by PCR and MAT in L1. A positive result either by PCR, MAT or

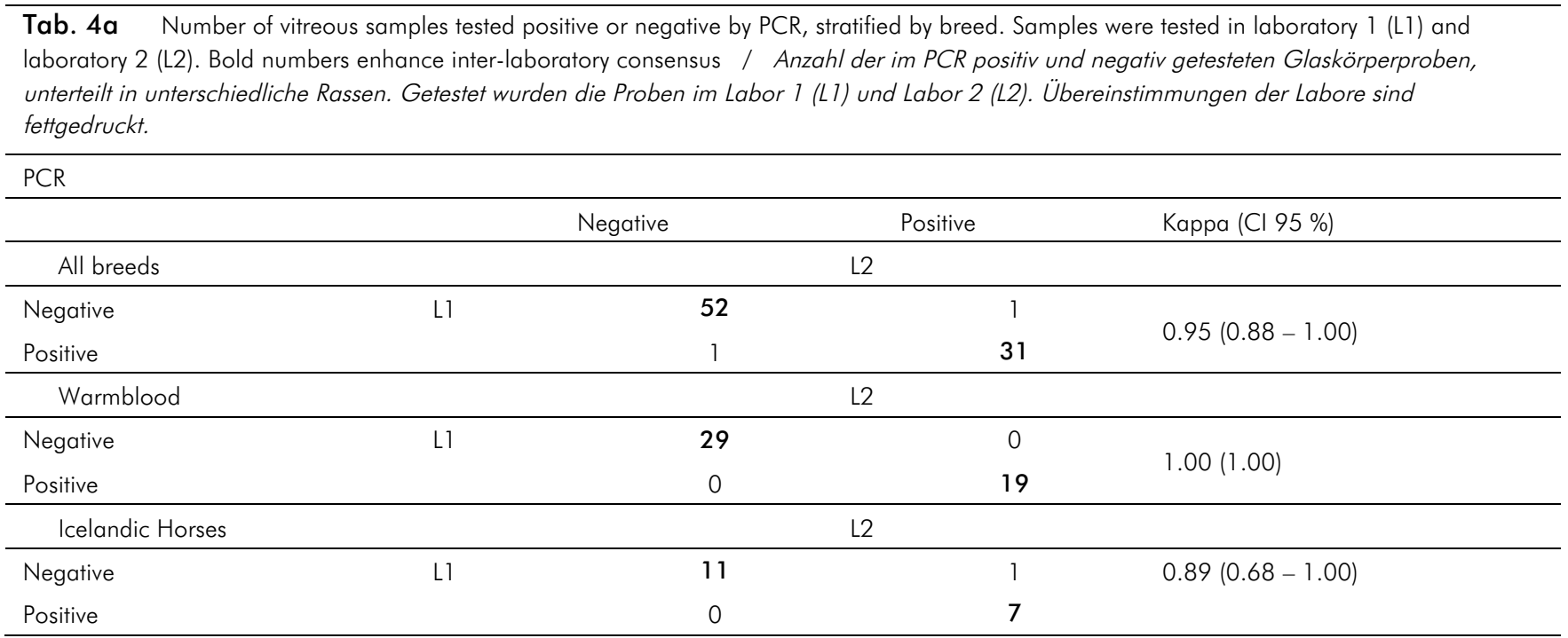

Tab. 4b Number of vitreous samples tested positive or negative by MAT stratified by breed. Samples were tested in laboratory 1 (L1) and laboratory 3 (L3). Bold numbers enhance inter-laboratory consensus. I Anzahl der im MAT positiv und negativ getesteten Glaskörperproben, unterteilt in unterschiedliche Rassen. Getestet wurden die Proben im Labor 1 (L1) und Labor 3 (L3). Übereinstimmungen der Labore sind fettgedruckt.

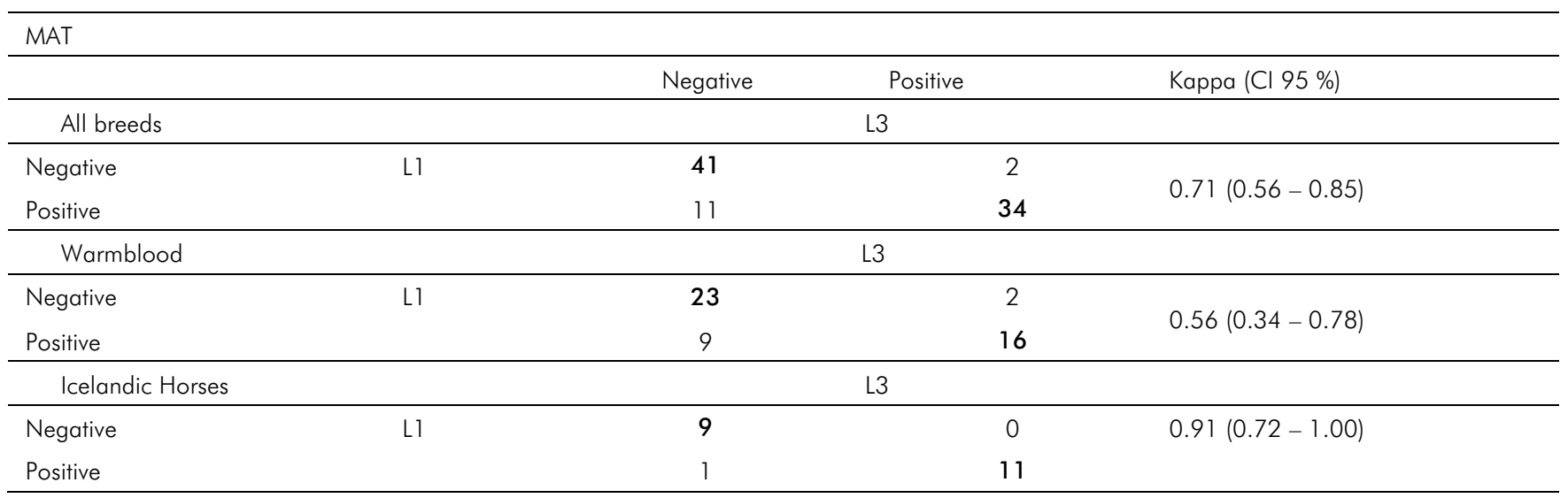


both tests combined was obtained in $54 \%$ (48) of the vitreal specimens examined in L1. Looking at the single tests, leptospiral DNA was detected in $38 \%$ (33) of the vitreal specimens. Fifty-two per cent (45) of the vitreal samples were positive in MAT for leptospiral antibodies against one or multiple leptospiral serovars. The antibodies detected most commonly were directed against serovar Grippotyphosa (39/45) and against serovar Pomona (6/45).

Vitreal samples examined for leptospiral DNA by L2 had a positive result in 38\% (33/89) of the eyes sampled.

Overall, 72 vitreal samples were available for MAT, ELISA and culture simultaneously in L3. The MAT was positive in $40 \%$ (29) of the eyes tested. Whereas, using the ELISA, $56 \%$ (40) of the vitreal samples were positive. Live leptospiral bacteria were cultured in $15 \%$ (11) of the vitreal specimens. Combining these examinations, leptospiral antibodies or Leptospira spp. was detectable in a total of $60 \%$ (43) of the vitreal specimens in L3.

The isolate detected mainly via culture in 12 of the 75 vitreal samples was serovar Grippotyphosa (10). In correlation with this, the MAT revealed antibodies most commonly against serovar Grippotyphosa (31/39) and serovar Pomona (8/31). Although results from the MAT were negative in $L 3$, a successful cultivation occurred in three samples. Two of these three samples revealed a positive MAT in L1 for the same serovar as that detected by culture in L3. One of these samples was negative in MATs from both laboratories (L1 and L3). The $P C R s$ in $L 1$ and $L 2$ were able to detect leptospiral antigen in each of these three specimens.

Calculation of dilution was carried out by supposing a ratio of vitreous to serum urea concentrations of 0.91 (McLaughlin B. G., 1988). The dilution of 34 samples taken at the beginning of vitrectomy ranged between 1 and 2.1, with a standard deviation of 1.68. The serial dilution analysis of the two enucleated globes showed a consistent decrease of the antibody titre in horse B, whereas the antibody titre for serovar Grippotyphosa stayed as high as 1:3.200. The laboratory performed a dilution of 1:6.400, but it did not reveal an agglutination of $50 \%$. The PCR stayed positive in all samples except in the second sample (dilution 1:1) of horse A (Tab. 6).

\section{Discussion}

All horses included in this study met the criteria for the "classic ERU" outlined by Gilger et al. (2010) and were, therefore, potential candidates for an ERU induced by leptospires (Wollanke et al. 2004). All horses had a clinical history of at least two painful episodes of ocular inflammation, including the anterior and/or posterior part of the eye. Since almost all patients were resident in northern Germany, this study provides a valuable local survey about the classic form of ERU potentially induced by leptospires, on the one hand, and the classic form of ERU without leptospiral involvement, on the

Tab. 5 Number of vitreal samples tested by Laboratory 1 (L1) and Laboratory 3 (L3). Bold numbers enhance inter-laboratory consensus. I Anzahl der Glaskörperproben untersucht von Labor 1 (L I) und Labor 3 (L3). Übereinstimmungen der Labore sind fettgedruckt.

\begin{tabular}{|c|c|c|c|c|}
\hline \multicolumn{5}{|c|}{ MAT $(n=88)$} \\
\hline & & Negative & Positive & Kappa (95\% Cl) \\
\hline \multicolumn{2}{|c|}{ All serovars } & \multicolumn{2}{|c|}{ L3 } & \\
\hline Negative & L1 & 41 & 2 & \multirow{2}{*}{$0.71(0.56-0.85)$} \\
\hline Positive & & 11 & 34 & \\
\hline \multicolumn{5}{|c|}{ Grippotyphosa } \\
\hline Negative & L1 & 47 & 2 & \multirow{2}{*}{$0.67(0.52-0.82)$} \\
\hline Positive & & 12 & 27 & \\
\hline \multicolumn{5}{|c|}{ Pomona } \\
\hline Negative & Ll & 81 & 1 & \multirow{2}{*}{$0.82(0.58-1.00)$} \\
\hline Positive & & 1 & 5 & \\
\hline
\end{tabular}

\begin{tabular}{|c|c|c|c|c|}
\hline Horse & Dilution & PCR L1 & MAT LI & Serovar \\
\hline \multirow[t]{3}{*}{ A } & Undiluted & + & + & $\begin{array}{l}\text { Grippotyphosa }(1: 3200) \\
\text { Icterohaemorrhagiae }(1: 100)\end{array}$ \\
\hline & $1: 1$ & - & + & $\begin{array}{l}\text { Grippotyphosa }(1: 3200) \\
\text { Icterohaemorrhagiae }(<1: 100)\end{array}$ \\
\hline & $1: 3$ & + & + & $\begin{array}{l}\text { Grippotyphosa }(1: 3200) \\
\text { Icterohaemorrhagiae }(<1: 100)\end{array}$ \\
\hline \multirow[t]{3}{*}{ B } & Undiluted & + & + & $\begin{array}{l}\text { Australis }(1: 800) \\
\text { Bratislava }(1: 200)\end{array}$ \\
\hline & $1: 1$ & + & + & $\begin{array}{l}\text { Australis }(1: 400) \\
\text { Bratislava }(1: 200)\end{array}$ \\
\hline & $1: 3$ & + & + & $\begin{array}{l}\text { Australis }(1: 200) \\
\text { Bratislava }(1: 200)\end{array}$ \\
\hline
\end{tabular}


other hand. All breeds of vitrectomized horses were included and the patient population seemed appropriately described with a mean age of 8.1 years ( 4.5 to 23.4 years).

In the present study, vitreal material was used to detect intraocular leptospiral DNA, antibodies and Leptospira. But it was shown that these intraocular leptospiral traces can be detected in aqueous humor, too (Faber et al. 2000, Polle et al. 2014, Schwink et al. 1989, Tömördy et al. 2010). A steady-state passive diffusion between the vitreous body and the aqueous humor has been described in rabbits. The rate of diffusion was depending on the size of molecules and on the rate of diffusion in the vitreous itself (Johnson et al. 1984, Maurice 1987). Since a steady diffusion between the aqueous and vitreous humor can be assumed for the equine eye as well, a comparable detection rate of leptospiral DNA, antibodies and Leptospira can be presumed. Still, a possible difference of the detectionrate between the aqueous humor and the vitreous body has not been evaluated yet. The MAT on paired serum samples is one of the tests most frequently used to verify a leptospiral infection in humans (OiE 2014). The prevalence of leptospiral antibodies usually measured via the MAT varies greatly in horses in a multitude of serological surveys. The seroprevalence of leptospiral antibodies ranged between 5 and $95 \%$ in horses, depending on the age and the geographic location of the residence of the horse (Kitson-Piggot et al. 1987, Lees et al. 1994, Rocha et al. 2004, Ye et al. 2014). Usually titers $\geq 1: 100$ were rated as positive, only Kitson-Piggot et al. (1987) rated a titer $\geq 1: 80$ as positive, but only $5 \%$ of the three year old horses showed a positive result. No significant difference in the serological results between unaffected horses from a control group and those affected with ERU could be ascertained (Faber et al. 2000). A serological evaluation of the horses, therefore, was not performed in the present study.

A wide range of studies investigated the utilisation of the MAT on vitreal or aqueous humor samples in horses to validate a correlation between intraocular antibodies against Leptospira spp. and ERU (Brandes et al. 2007, Brem et al. 1998, and 1999, Bryans 1955, Davidson et al. 1987, Polle et al. 2014, von Borstel et al. 2010, Wollanke et al. 1998, Wollanke et al. 2004, Wollanke et al. 2000, Wollanke et al. 2001). In these studies, the amount of positive results for intraocular leptospiral antibodies ranged between 35 and $94 \%$ (Brandes et al. 2007, Brem et al. 1999, Dorrego-Keiter 2016, Gerding et al. 2015, Gilger et al. 2008, Polle et al. 2014, von Borstel et al. 2010, Wollanke et al. 1998, Wollanke et al. 2001) of the eyes tested. In the present study the positive MAT-results ranged between 41 and $51 \%$ in L1 and L3. One reason for this variation in results might have been the use of different laboratories. In the present study, the conformity of the MAT between L1 and L3 was dependent upon the breed of the horse sampled, and also upon the serovars detected. The interlaboratory agreement was almost perfect for serovar Pomona and only substantial for serovar Grippotyphosa (Tab. 5). In addition, the titres for serovar Grippotyphosa from L1 were almost consistently higher than those from L3 (Fig. 1). This substantial variation of agreement between laboratories might be accounted for by the utilisation of different strains from the same leptospiral serotype (Combiescu et al. 1958). Distinction of leptospires was first carried out by defining two different species based upon different phenotypes and nutritional requirements (Johnson et al. 1964). Leptospires were classi- fied later serologically on the basis of different agglutination patterns (Kmety et al. 1993). Throughout the years it became apparent that serologic typing can be imprecise. The reason for this was supposed to be cross-agglutination between congeneric strains (Kmety et al. 1993, Turner 1968). The identification of serovars via the MAT was based upon using locally specific serovars for agglutination (OiE 2014) and results were determined by the quality of matching between the possible antibodies and leptospiral strains utilised (Kmety et al. 1993). The higher agglutination titres for serovar Grippotyphosa in L1 compared to L3 were assumed to be a consequence of different strains of the same serovar used in the laboratories. The strain for serovar Grippotyphosa used in L1 seemed to be more appropriate for the horses sampled in this study. This finding was in accordance with recent studies also investigating the differences between MAT results in different laboratories. One study was able to show a serovar-dependent Kappa between laboratories (Fang et al. 2014). Another study performing worldwide inter-laboratory trials showed that laboratories which attended in the first round revealed higher titres of the same serovars in the second round than laboratories which solely attended in the second round (Chappel et al. 2004). If findings from MAT were stratified by breed in the present study, Warmblood horses appeared to have only a moderate inter-laboratory agreement of MAT results, while Icelandic horses exhibited an almost perfect agreement between laboratories (Tab. 4b). The differing degrees of agreement in the MAT between L1 and L3 for Warmblood and Icelandic horses might have been an indicator of dissimilar strains of leptospires inducing antibody production in these breeds. Intraocular leptospiral antibodies from the Icelandic horses with ERU appeared to be a better match for the live leptospiral strain utilised in L3 than the leptospiral antibodies gained from vitreal samples of Warmblood horses with ERU. The antibodies detected most frequently agglutinated with serovar Grippotyphosa in both breeds. A study from 2012 indicated a higher risk for Icelandic horses to have intraocular leptospiral antibodies, when compared to Warmblood horses (Wiehen 2012). A higher prevalence of Icelandic horses to positive test results for intraocular leptospiral antibodies or for intraocular leptospiral DNA was not evident in the current study.

Another potential trouble spot of cross-agglutination had to be considered when MAT results were interpreted with regard to serovars. Several studies indicated that the MAT was epidemiologically unreliable for the detection of the causative leptospiral serovar (Kusum et al. 2005, Levett 2003, Smythe et al. 2009). The cultivation was assumed to be the gold standard for identifying the serovar responsible (Gochenour Jr et al. 1953). The main serovar detected in the present study via cultivation in L3 was serovar Grippotyphosa, which was in accordance with the serovar mostly detected by MAT. Therefore, a better reliability of the MAT with regard to serovar detection was assumed for this study.

The ELISA is an indirect test to screen for leptospiral antibodies. The MAT was normally used to validate an ELISA (OiE 2014). Since the MAT results need to be regarded carefully for interpretation, as outlined above, the ELISA is an improper test to safely identify leptospiral infection in equine patients. $A$ higher sensitivity of the ELISA can be achieved by combining multiple recombinant proteins of a specific serovar in one test (Ye et al. 2014). 
During the last two decades, major achievements in the field of detecting leptospiral DNA from different tissues were made to improve the rapidity and to lower the costs of diagnosing an early leptospiral infection in humans before antibodies were traceable (Bal et al. 1994, Brown et al. 1995, Gravekamp et al. 1993, Kee et al. 1994, Merien et al. 1992). Interestingly, the current study indicated a strong conformity between $L 1$ and $L 2$, although different techniques were used and different genes were targeted. One reason for this strong conformity may have been a similar sensitivity regardless of which technique was used. The sensitivity of distinct PCR protocols for detecting leptospiral DNA in different sample materials was tested in various studies by the use of dilution series. One study, amplifying the Leptospira rrs (16S) gene, demonstrated that a minimum of two to ten bacteria per millilitre of sample material revealed a positive PCR result (Merien et al. 1992). Another study, using a real-time PCR to amplify the $\mid \mathrm{fb} 1$, secY and lipL32 gene, reported a limit of detection of one bacterium or five genome equivalents per microlitre of sample material per PCR (Bourhy et al. 2011 ). Hence, the PCR was a very sensitive method and only a high sample dilution combined with very low amounts of leptospiral DNA seemed to minimise this sensitivity. The MAT, on the other hand, had a sensitivity of about $30-76 \%$, referring to a prospective study on human serous samples from Barbados (Cumberland et al. 1999). The sensitivity increased from samples taken in the acute phase to the samples taken during convalescence (median 28 days after the first symptoms). Since it was shown that the onset of ERU after a potential infection with leptospires takes months to years (Williams et al. 1971), it could be assumed that the sensitivity of convalescent samples had the highest relevance for vitreal specimens from horses with ERU.

Cultivation of leptospires was shown to require weeks to months of incubation time (Levett 2001), and offered only a poor sensitivity (Adler et al. 2010). If leptospires were successfully cultivated, their identification was performed by molecular techniques or serological methods, such as the cross-agglutinin absorption (Dikken et al. 1978, Fletcher 1928). Successful cultivation in the current study was possible in $16 \%(12 / 75)$ of the vitreal specimens. This is in accordance with a recent study that analysed 212 undiluted vitreal specimens (Dorrego-Keiter 2016). Interestingly, a cultivation of leptospires was possible in three vitreal specimens, although no antibodies were detected in L3 in the MAT. The MAT performed in L1 identified leptospiral antibodies in two of these three samples, whereas L1 and L2 detected leptospiral DNA in all of the three specimens. This supports the theory that the MAT in L3 might have missed a few leptospiral antibodies due to usage of a different leptospiral strain. However, in one sample, neither L3 nor L2 detected leptospiral antibodies during the MAT. An unlikely reason for this might be an early stage of infection, thus, leptospiral antibodies were not yet detectable. This seemed rather unlikely, due to the clinical history of a "classic ERU". Leptospiral antibodies are produced during the first 10-14 days after infection with leptospires (Adler et al. 2010). A more likely explanation might be that leptospiral strains from both laboratories (L1 and L3) were a poor fit for possible antibodies in this case. The low number of leptospires cultivated in this study might have been due to a lack of living leptospires in the vitreal body at the time of the vitrectomy. An additional reason for a low rate of cultivation could have been the dilution of samples during vitrecto- my with flushing medium containing gentamicin. This might have interfered with cultivation attempts, because Gentamicin seems to have bactericidal effects on leptospires (Kobayashi 2001, Kobayashi 2005) and might have led to false negative results in the present study. Wollanke et al. (2000) compared diluted with undiluted vitreal specimens. They diluted approximately $25 \mathrm{ml}$ of vitreal body with $250 \mathrm{ml}$ (1:10) of balanced salt solution with $20 \mathrm{mg}$ of gentamicin during vitrectomy $(80 \mu \mathrm{g} / \mathrm{ml}$ gentamicin). They were able to cultivate living leptospires in $7 \%(6 / 92)$ of the diluted samples and in $39 \%$ $(41 / 104)$ of the undiluted vitreal samples. This increase in successful cultivations might either be due to the lower quantitative dilution of vitreal samples, or it was due to the absence of gentamicin in the vitreal samples. Nevertheless, an intravenous treatment with enrofloxacin prior to vitrectomy did not alter the cultivation of leptospires from vitreal samples significantly (Popp et al. 2013). Besides the influence of gentamicin on cultivation attempts, its retinal toxicity needs to be considered (D'amico et al. 1984, Hancock et al. 2005, Mochizuki et al. 1988). Not only the gentamicin-concentration, but also the ocular pigmentation and the manner of application can influence the toxic effects of gentamicin on the retina (Peyman et al. 1974, Zemel et al. 1995). Even very low amounts of undiluted gentamicin $(30 \mu \mathrm{g})$ injected into the vitreous body with the tip of the needle pointing to the retina can cause damage to the retina, whereas an amount of $200 \mu \mathrm{g}$ of gentamicin did not cause any damage, if the needle was pointed to the anterior segment (Peyman et al. 1974). Gentamicin is a strong acid and its toxic effects on the retina may be due to a direct $\mathrm{pH}$-effect on the retinal vasculature and neurons (Hancock et al. 2005, Snider et al. 1985). The gentamicin-concentration of flushing solution used for vitrectomy of horses varies in the literature between $80 \mu \mathrm{g} / \mathrm{ml}$ and $200 \mu \mathrm{g} / \mathrm{ml}$ as far as noted, and no toxic side effects of the gentamicin in the flushing solution were described so far. This might be due to the high volume of flushing solution (250 to $500 \mathrm{ml}$ ) used during vitrectomy (Frühauf 1998, Gerhards et al. 1999, von Borstel et al. 2005, Wollanke et al. 2000).

It has been described anecdotally that intravitreal genatmicininjections $(400 \mu \mathrm{g})$ may decrease or prevent further recurrences in eyes with ERU (Gilger 2010). Therefore, it is conceivable that not only the exchange of the vitreal body with the inflammatory debris in it, but also the concentration of gentamicin in the flushing solution may have an influence on preventing further inflammatory recurrences.

One limitation of this study was that only diluted vitreal samples were available. Some authors described obtaining undiluted vitreal material during vitrectomy of horses with ERU by aspiration of the vitreal material at the beginning of the pars plana vitrectomy, before opening the infusion line with balanced salt solution (Loib/2009, Popp 2011 , Wiehen 2012). Complications, such as retinal bleeding, pupil constriction and choroidal haemorrhages, were described in human patients for sampling the vitreous without immediate volume replacement (Quiroz-Mercado et al. 2005). Complications recorded during pars plana vitrectomy in equine patients are retinal detachment and vitreal and/or retinal haemorrhage (Frühauf 1998, von Borstel et al. 2005, Werry and Gerhards 1991, Werry et al. 1992). Therefore, this approach was not used on patients in the present study with respect to possible complications. To minimise these intraoperative complica- 
tions, different techniques to obtain undiluted vitreal biopsies from human patients without losing intravitreal volume were described in the literature. One of them used air instead of a liquid solution at the beginning of the vitrectomy to collect between 1.5 and $4 \mathrm{ml}$ of undiluted vitreal material (Tsui et al. 2010). In other studies, authors used perfluorocarbon liquids instead of balanced salt solution (Quiroz-Mercado et al.2005, Yu et al. 2014). Perfluorocarbon liquids are synthetic compositions with physical characteristics that make it a very useful aid in ocular surgery (Kramer et al. 1995). They are transparent liquids with a high specific gravity, a low viscosity and a surface tension that is good in aqueous solutions (Berrocal 1994). Thus, filling the eye from posterior to anterior (Kramer et al. 1995) and making it an ideal tool to gain undiluted vitreal material without risking a sudden decrease in intraocular pressure. Even if perfluorocarbon liquids get mixed with the vitreal specimen, postoperative separation by different gravities or by freezing the specimen can be carried out (Quiroz-Mercado et al. 2005). Since there was no information about any utilisation of perfluorocarbon liquids or air instead of flushing solution in equine ocular surgery and adverse effects in equine patients are unknown, this tool was not used on the equine patients undergoing vitrectomy in this study. Instead of risking complications during or after vitrectomy while gaining undiluted vitreal samples for scientific purposes from each horse, the compromise of a minimal sample dilution was accepted in the present study.

This dilution might not only have influenced the results of cultivation due to the gentamicin-concentration in the specimens, but also the results of antibody and antigen detection by PCR and MAT, because of a quantitative dilution. Detection of leptospiral antibodies could have been improved by testing undiluted specimens. Wollanke et al. (2000) were able to detect leptospiral antibodies in $67 \%$ of the 1:10 diluted specimens via MAT, while the undiluted vitreal body revealed detectable antibodies in $79 \%$ of the samples in the same study. This amount of increase in detection could not be expected in the present study, because the maximum dilution measured during the dilution testing was 1:3.8. Furthermore, results from the serial dilution (Tab. 6) indicated a negligible influence of a dilution as high as 1:3 on the test results. It was shown in horse $A$ that the antibody titre for serovar Grippotyphosa was not altered by dilution (Tab. 6). Although it is likely that the dilution altered the amount of antibodies in the specimen, this happened within the range for the titer of $1: 3.200$. However, it has to be kept in mind that a few cases of intraocular leptospiral traces might still be disregarded if vitreous was diluted. Nevertheless, even with respect to dilution of the samples, no leptospiral involvement was provable in more than one third of the vitreal specimens. A total of $43 \%(29 / 67)$ of the vitreal samples tested were negative in all tests performed in all three laboratories (Tab. 3). Compared to the results of $L 1,46 \%(41 / 89)$ of the eyes revealed a negative result for leptospiral DNA and no agglutination of the leptospiral MAT. Alternatively, $54 \%$ (48/89) of the eyes tested in $\mathrm{L} 1$ evinced a positive result either in PCR or in MAT. Consequently, this showed that most of the positive specimens could be obtained by combining PCR and MAT results only from L1. This is supported by a study comparing serological tests with the PCR in human leptospirosis. De Abreu Fonseca et al. (de Abreu Fonseca et al. 2006) used 124 serum sam- ples of validated leptospirosis cases, 20 specimens from humans with other febrile diseases and 44 specimens from healthy individuals. The combination of leptospiral PCR and MAT showed a sensitivity of $100 \%$ in specimens taken at day 9 post infection or later. Since most of the leptospirosis cases validated in this study also seemed to be discovered by the combination of the MAT with the PCR in L1, a necessity for the use of more than one laboratory could, thus, be denied with regard to the tests performed.

Results indicated a strong inter-laboratory agreement when PCR was used for the detection of leptospiral DNA, whereas the MAT showed a variance of results that needs to be carefully regarded for interpretation. Therefore, basing a decision against a pars plana vitrectomy only upon a negative MAT result of anterior chamber fluid from a single laboratory could not be recommended.

\section{Manufacturer's addresses}

1 BSS PLUS ${ }^{\circledR}$, Alcon Laboratories, Inc., Texas, USA (balanced salt solution enriched with bicarbonate, dextrose and glutathione)

2 Gentamicin-ratiopharm ${ }^{\circledR} 80 \mathrm{mg} / 2 \mathrm{ml}$ SF, Ratiopharm $\mathrm{GmbH}$, Ulm, Germany

3 VersaVIT ${ }^{T M}$ Vitrectomy System, Synergetics Inc., Missouri, USA

4 Flushing solution: $500 \mathrm{ml} \mathrm{BSS} \mathrm{PLUS}{ }^{\circledR}$ charged with $80 \mathrm{mg}$ gentamicin $(160 \mu \mathrm{g} / \mathrm{ml})$

\section{References}

Adler B., de la Peña Moctezuma A. (2010) Leptospira and leptospirosis. Veterinary Microbiology, 140, 287-296. doi: http://dx.doi.org/10.1016/i.vetmic.2009.03.012

Alexander K. (1990) Ätiologie und Vorkommen der periodischen Augenentzündung des Pferdes im Raum Berlin. Tierarztliche Praxis, $18,623-627$

Angelos J., Oppenheim Y., Rebhun W., Mohammed H., Antczak D. $F$. (1988) Evaluation of breed as a risk factor for sarcoid and uveitis in horses. Animal genetics, 19, 417-425

Bal A., Gravekamp C., Hartskeerl R., De Meza-Brewster J., Korver H., Terpstra W. (1994) Detection of leptospires in urine by PCR for early diagnosis of leptospirosis. J. Clini. Microbiol. 32, 18941898

Berrocal C. (1994) Perfluorocarbon liquids in vitreous surgery. Ophthalmol. Clin. North Am. 7, 67-76

Böhm L., Supperer R. (1954) Weitere Untersuchungen über Mikrofilarien als Erreger der Periodischen Augenentzündung der Pferde. Wien. Tierärztl. Mschr. 41, 129-139

Bourhy P., Bremont S., Zinini F., Giry C., Picardeau M. (2011) Comparison of real-time PCR assays for detection of pathogenic Leptospira spp. in blood and identification of variations in target sequences. J. Clin. Microbiol. 49, 2154-2160. doi: 10.1128/ jcm.02452-10

Brandes K., Wollanke B., Niedermaier G., Brem S., Gerhards H. (2007) Recurrent uveitis in horses: vitreal examinations with ultrastructural detection of leptospires. J. Vet. Med. A, 54, 270-275

Brem S., Gerhards H., Wollanke B., Meyer P., Kopp H. (1998) Demonstration of intraocular leptospira in 4 horses suffering from equine recurrent uveitis (ERU). Berl. Münch. Tierärztl. Wsch. 111 , 415-417

Brem S., Gerhards H., Wollanke B., Meyer P., Kopp H. (1999) 35 leptospira isolated from the vitreous body of 32 horses with recurrent uveitis (ERU). Berl. Münch. Tierärztl. Wsch. 112, 390-393 
Brown P. D., Gravekamp C., Carrington D. G., van de Kemp H., Hartskeerl R. A., Edwards C. N., Levett P. N. (1995) Evaluation of the polymerase chain reaction for early diagnosis of leptospirosis. J. Med. Microbiol. 43, 110-1 14. doi: 10.1099/00222615-43-2-110

Bryans J. T. (1955) Studies on equine leptospirosis. The Cornell veterinarian, 45, 16-50.

Cello R. M. (1971) Ocular onchocerciasis in the horse. Equine Vet. J. 3, 148-154

Chappel R. J., Goris M., Palmer M. F., Hartskeerl R. A. (2004) Impact of proficiency testing on results of the microscopic agglutination test for diagnosis of leptospirosis. J. Clin. Microbiol. 42, 54845488. doi: 10.1128/jcm.42.12.5484-5488.2004

Combiescu D., Sturdza N., Sefer M., Radu I. (1958) Research on leptospirosis in Rumania. Zentralblatt fur Bakteriologie, Parasitenkunde, Infektionskrankheiten und Hygiene. 1. Abt. Medizinisch-hygienische Bakteriologie, Virusforschung und Parasitologie. Originale, $173,103-106$

Cumberland P., Everard C. O., Levett P. N. (1999) Assessment of the efficacy of an IgM-elisa and microscopic agglutination test (MAT) in the diagnosis of acute leptospirosis. Am. J. Trop. Med. Hyg. 61, $731-734$

D'amico D., Libert J., Kenyon K., Hanninen L., Caspers-Velu L. (1984) Retinal toxicity of intravitreal gentamicin. An electron microscopic study. Invest. Ophthalmol. Visual sci. 25, 564-572

Davidson M. G., Nasisse M. P., Roberts S. M. (1987) Immunodiagnosis of leptospiral uveitis in two horses. Equine Vet. J. 19, 155157

de Abreu Fonseca C., Teixeira de Freitas V. L., Calo Romero E., Spinosa C., Arroyo Sanches M. C., da Silva M. V., Shikanai-Yasuda M. A. (2006) Polymerase chain reaction in comparison with serological tests for early diagnosis of human leptospirosis. Trop. Med. Intern. Health 11, 1699-1707. doi: 10.1111/j.13653156.2006.01727.x

Deeg C. A. (2008) Ocular immunology in equine recurrent uveitis. Veterinary ophthalmology, 11 Suppl 1, 61-65. doi: 10.1111/j.1463-5224.2008.00625.x

Deeg C. A. (2009) A proteomic approach for studying the pathogenesis of spontaneous equine recurrent uveitis (ERU). Vet. Immunol. Immunopathol. 128, 132-136. doi: 10.1016/i.vetimm.2008.10. 302

Deeg C. A., Thurau S. R., Gerhards H., Ehrenhofer M., Wildner G., Kaspers B. (2002) Uveitis in horses induced by interphotoreceptor retinoid-binding protein is similar to the spontaneous disease. European journal of immunology, 32, 2598-2606. doi: 10.1002/1521-4141(200209)32:9<2598::aid-immu2598> 3.0.co;2-\#

Dikken H., Kmety E. (1978) Serological typing methods of leptospires. Meth. Microbiol. 11, 259-307

Dorrego-Keiter E. T. J., Dikker L., Sielhorst J., Schusser G. F. (2016) Detection of leptospira by culture of vitreous humor and detection of antibodies against leptospira in vitreous humor and serum of 225 horses with equine recurrent uveitis. Berl. Münch. Tierärztl. Wschr. 129, 209-215. doi: 10.2376/0005-9366-129-15085

Dwyer A. E., Crockett R. S., Kalsow C. M. (1995) Association of leptospiral seroreactivity and breed with uveitis and blindness in horses: 372 cases (1986-1993). J. Am. Vet. Med. Assoc. 207, 1327-1331

Faber N. A., Crawford M., LeFebvre R. B., Buyukmihci N. C., Madigan J. E., Willits N. H. (2000) Detection of Leptospira spp. in the Aqueous Humor of Horses with Naturally Acquired Recurrent Uveitis. Clin. Microbiol. 38, 2731-2733

Fang F., Collins-Emerson J. M., Hever C., Hill F. I., Tisdall D. J., Wilson P. R.,Benschop J. (2014) Interlaboratory and between-specimen comparisons of diagnostic tests for leptospirosis in sheep and cattle.Vet. Diag. Invest. 26, 734-747. doi: 10.1177/10406387 14548476

Fletcher W. (1928) Recent work on leptospirosis, tsutsugamushi disease, and tropical typhus in the Federated Malay States. Transact. Royal Soc. Trop. Med. Hyg. 21, 265-IN269

Frellstedt L. (2009) Equine recurrent uveitis: A clinical manifestation of leptospirosis. Equine Vet. Educ. 21, 546-552. doi: 10.2746/ $095777309 \times 467853$
Fritz K. L., Kaese H. J., Valberg S. J., Hendrickson J. A., Rendahl A. K., Bellone R. R., McCue M. E. (2014) Genetic risk factors for insidious equine recurrent uveitis in Appaloosa horses. Anim. Genetics 45, 392-399. doi: 10.1111/age.12129

Frühauf O., Deegen E., Boevé M. H. (1998) Surgical Management of equine recurrent uveitis with single port pars plana vitrectomy. Vet. Ophthalmol. 1, 137-151

Gerding J. C., Gilger B. C. (2015) Prognosis and impact of equine recurrent uveitis. Equine Vet. J. doi: 10.1111/evj.12451

Gerhards H., Wollanke B., Brem S. (1999) Vitrectomy as a diagnostic and therapeutic approach for equine recurrent uveitis (ERU). Proceedings 45th Ann. Conv. AAEP, Albuquerque, 89-93.

Gilger B. C. (2010) Equine recurrent uveitis The viewpoint from the USA. Equine Vet : J. 37, 57-61. doi: 10.11111/042516409X090 002

Gilger B. C., Salmon J. H., Na Y. Y., Barden C. A., Chandler H. L., Wendt J. A., Colitz C. M. (2008) Role of bacteria in the pathogenesis of recurrent uveitis in horses from the southeastern United States. Am. J.Vet. Res. 69, 1329-1335

Gilger B. C., Wilkie D. A., Clode A. B., McMullen R. J., Jr., Utter M. E., Komaromy A. M., Salmon J. H. (2010) Long-term outcome after implantation of a suprachoroidal cyclosporine drug delivery device in horses with recurrent uveitis. Vet. Ophthalmol 13, 294300. doi: 10.1111/i.1463-5224.2010.00807.x

Gochenour Jr W. S., Yager R. H., Wetmore P. W., Hightower J. A. (1953) Laboratory Diagnosis of Leptospirosis. American Journal of Public Health and the Nations Health, 43, 405-410.

Gravekamp C., van de Kemp H., Franzen M., Carrington D., Schoone G. J., Van Eys G. J., Terpstra W. J. (1993) Detection of seven species of pathogenic leptospires by PCR using two sets of primers. General Microbiol. 139, 1691-1700. doi: 10.1099/ 00221287-139-8-1691

Halliwell R. E., Brim T. A., Hines M. T. , Wolf D., White F. H. (1985) Studies on equine recurrent uveitis II The role of infection with Leptospira interrogans serovar pomona. Current Eye Res. 4, 1033-1040

Hancock H. A., Guidry C., Read R. W., Ready E. L., Kraft T. W. (2005) Acute aminoglycoside retinal toxicity in vivo and in vitro. Invest. Ophthalmol. Visual sci. 46, 4804-4808. doi: 10.1167/iovs.050604

Hartskeerl R. A., Goris M. G. A., Brem S., Meyer P., Kopp H., Gerhards H., Wollanke B. (2004) Classification of Leptospira from the Eyes of Horses Suffering from Recurrent Uveitis. J. Vet. Med. B 51, 110-115. doi: 10.1111/j.1439-0450.2004.00740.x

Heusser H. (1948) Die periodische Augenentzündung, eine Leptospirose. Schweiz. Arch. Tierheilk. 90, 287-314

Johnson F., Maurice D. (1984) A simple method of measuring aqueous humor flow with intravitreal fluoresceinated dextrans. Experiment. Eye Res. 39, 791-805

Johnson R. C., Rogers P. (1964) Differentiation of pathogenic and saprophytic leptospires with 8-azaguanine. Bacteriol. 88, 16181623

Kee S. H., Kim I. S., Choi M. S., Chang W. H. (1994) Detection of leptospiral DNA by PCR. Clin. Microbiol. 32, 1035-1039

Kitson-Piggot A., Prescott J. (1987) Leptospirosis in horses in Ontario. Can. J. Vet. Res. 51, 448

Kmety E., Dikken H. (1993). Classification of the species Leptospira interrogans and history of its serovars: University Press Groningen.

Kobayashi Y. (2001) Clinical observation and treatment of leptospirosis. J. Infec. Chemotherapy 7, 59-68

Kobayashi Y. (2005) Human leptospirosis: management and prognosis. J. Postgrad. Med. 51, 201

Kramer S. G., Hwang D., Peyman G. A., Schulman J. A., Sullivan B. (1995) Perfluorocarbon liquids in ophthalmology. Surv. Ophthalmol. 39, 375-395

Kulbrock M., Lehner S., Metzger J., Ohnesorge B., Distl O. (2013) A genome-wide association study identifies risk loci to equine recurrent uveitis in German warmblood horses. PLoS One, 8, e71619. doi: 10.1371/journal.pone.0071619

Kusum M., Boonsarthorn N., Biaklang M., Sina U., Sawanpanyalert P., Naigowit P. (2005) Comparison of leptospiral serovars identification by serology and cultivation in northeastern region, Thailand. J. Med. Assoc. Thai. 88, 1098-1102 
Landis J. R., Koch G. G. (1977) The measurement of observer agreement for categorical data. Biometrics 33, 159-174

Lees V. W., Gale S. P. (1994) Titers to Leptospira species in horses in Alberta. Can. Vet. J. 35, 636

Levett P. N. (2001) Leptospirosis. Clin. Microbiol. Rev. 14, 296-326 doi: $10.1128 / \mathrm{cmr}$. 14.2.296-326.2001

Levett P. N. (2003) Usefulness of serologic analysis as a predictor of the infecting serovar in patients with severe leptospirosis. Clin. Infect. Dis. 36, 447-452. doi: 10.1086/346208

Loib/ J. (2009) Immunologische und mikrobiologische Untersuchungen zur intraokular persistierenden Leptospireninfektion bei Pferden mit rezidivierender Uveitis. Diss. Med. Vet. München

Maurice D. M. (1987) Flow of water between aqueous and vitreous compartments in the rabbit eye. Am. J. Physiol. Renal Physiol. 252, F104-F108

McLaughlin B. G., McLaughlin.P. S. (1988) Equine Vitreous Humor Chemical Concentrations- Correlation with Serum Concentrations, and Postmortem Changes with Time and Temperature. Can. J. Vet. Res. 52, 476-480

Merien F., Amouriaux P., Perolat P., Baranton G., Saint Girons I. (1992) Polymerase chain reaction for detection of Leptospira spp. in clinical samples. J. Clin. Microbiol. 30, 2219-2224

Mochizuki K., Torisaki M., Kawasaki K., Shirao Y., Yamashita Y., Kitano K., Yonemura D. (1988) Retinal toxicity of antibiotics: Evaluation by electroretinogram. Doc. Ophthalmol. 69, 195-202

Niedermaier G., Wollanke B., Hoffmann R., Brem S., Gerhards H. (2006) Detection of leptospira in the vitreous body of horses without ocular diseases and of horses with equine recurrent uveitis (ERU) using transmission-electron microscopy. Deutsch. Tierärztl. Wschr. 113, 418-422

OiE (2014) Leptospirosis. from World organisation for animal health http://www.oie.int/international-standard-setting/terrestrial-manual/access-online/

Pearce J. W., Galle L. E., Kleiboeker S. B., Turk J. R., Schommer S. K., Dubielizig R. R., Giuliano E. A. (2007) Detection of Leptospira interrogans DNA and antigen in fixed equine eyes affected with end-stage equine recurrent uveitis. J. Vet. Diag. Invest. 19, 686-690

Peyman G., Paque J., Meisels H., Bennett T. (1974) Postoperative endophthalmitis: a comparison of methods for treatment and prophlaxis with gentamicin. Ophthal. Surg. 6, 45-55

Polle F., Storey E., Eades S., Alt D., Hornsby R., Zuerner R., Carter R. (2014) Role of Intraocular Leptospira Infections in the Pathogenesis of Equine Recurrent Uveitis in the Southern United States. J. Equine Vet. Sci. 34, 1300-1306. doi: 10.1016/i.jevs.2014.09. 010

Popp M. K. (2011) Enrofloxacin im Glaskörper an Equiner rezidivierender Uveitis erkrankter Pferde. Diss. Med. Vet. München

Popp M. K., Gerhards H., Wollanke B. (2013) Enrofloxacinkonzentrationen im Glaskörper und Serum von an equiner rezidivierender Uveitis (ERU) erkrankter Pferde nach wiederholter intravenöser Verabreichung. Pferdeheilkunde 29, 574-580

Priest H. L., Irby N. L., Schlafer D. H., Divers T. J., Wagner B., Glaser A. L., Smith M. C. (2012) Diagnosis of Borrelia-associated uveitis in two horses. Vet. Ophthalmol. 15, 398-405. doi: 10.1111/j. 1463-5224.2012.01000.x

Quiroz-Mercado H., Rivera-Sempertegui J., Macky T. A., NavarroLopez P., Griselda-Alvarez L., Ibarra-Ponce N., Moreno-Paramo D. (2005) Performing vitreous biopsy by perfluorocarbon-perfused vitrectomy. Am. J. Ophthalmol. 140, 1161 -1163. doi: 10.1016/i. ajo.2005.07.028

Regan D. P., Aarnio M. C., Davis W. S., Carmichael K. P., Vandenplas M. L., Lauderdale J. D., Moore P. A. (2012) Characterization of cytokines associated with Th17 cells in the eyes of horses with recurrent uveitis. Vet. Ophthalmol. 15, 145-152. doi: 10.1111/ j. 1463-5224.2011.00951.x

Rimpau W. (1947) Leptospirose beim Pferd (Periodische Augenentzündung). Tierärztl. Umsch. 2, 177-178

Roberts S. (1962) Fundus lesions in equine periodic ophthalmia. J. Am. Vet. Med. Assoc. 141, 229

Rocha T., Ellis W., Montgomery J., Gilmore C., Regalla J., Brem S. (2004) Microbiological and serological study of leptospirosis in horses at slaughter: first isolations. Res. Vet. Sci. 76, 199-202
Schmidt G. M., Krehbiel J. D., Coley S. C., Leid R. W. (1982) Equine ocular onchocerciasis: histopathologic study. Am. J. Vet. Res. 43, $1371-1375$

Schwink K., Crisman M., Rigg D. (1989) Chronic recurrent uveitis in a horse with an elevated aqueous humor antibody titer to Leptospira interrogans serovar autumnalis. Equine Prac. 11, 41-43

Sillerud C. L., Bey R. F., Ball M.,Bistner S. I. (1987) Serologic correlation of suspected Leptospira interrogans serovar pomona-induced uveitis in a group of horses. J. Am. Vet. Med. Assoc.191, 1576-1578

Smythe L. D., Wuthiekanun V., Chierakul W., Suputtamongkol Y., Tiengrim S., Dohnt M. F., Peacock S. J. (2009) The microscopic agglutination test (MAT) is an unreliable predictor of infecting Leptospira serovar in Thailand. Am. J. Trop. Med. Hyg. 81, 695-697 doi: 10.4269/ajtmh.2009.09-0252

Snider J., Cohen H., Chenoweth R. (1985). Acute ischemic retinopathy secondary to intraocular injection of gentamicin Retinal Diseases. Grune \& Stratton Orlando FL., 227-232

Spiess B. M. (2010) Equine recurrent uveitis: the European viewpoint. Equine Vet. J. Supplement, 50-56.

Tömördy E., Haessig M., Spiess B. M. (2010) The outcome of pars plana vitrectomy in horses with equine recurrent uveitis with regard to the presence or absence of intravitreal antibodies against various serovars of Leptospira interrogans. Pferdeheilkunde 26, 251-254

Tsui I., Schwartz S. D., Hubschman J.-P. (2010) A current method to collect an undiluted vitrectomy sample. Retina 30, 830-831

Turner L. H. (1968) Leptospirosis. II. Serology. Transact. Royal Soc. Trop. Med. Hyg. 62, 880-899

von Borstel M., Oey L., Strutzberg-Minder K., Boeve M. H., Ohnesorge B. (2010) Direct and indirect detection of leptospires in vitreal samples of horses with ERU. Pferdeheilkunde 26, 219-225 von Borstel M., Von Oppen T., Glitz F., Frühauf B., Deegen E., Boeve M. H., Ohnesorge B. (2005) Long-term results of pars-plana (double-port) vitrectomy in equine recurrent uveitis. Pferdeheilkunde 21, 13-18

Werry H., Gerhards H. (1992) [The surgical therapy of equine recurrent uveitis]. Tierärztl Praxis 20, 178-186

Werry H., Gerhards H. (1991) Möglichkeiten der und Indikationen zur chirurgischen Behandlung der equinen rezidivierenden Uveitis (ERU). Pferdeheilkunde 7, 321-331

Wiehen L. E. (2012). Retrospektive Analyse zum Vorkommen der Equinen rezidivierenden Uveitis -unter Berücksichtigung der Leptospireninfektion- an der LMU München von 01.2005 bis 06.2010. Diss. Med. Vet. München

Williams R., Morter R., Freeman M., Lavignette A. (1971) Experimental chronic uveitis. Ophthalmic signs following equine leptospirosis. Invest. Ophthalmol. 10, 948-954

Winterberg G. (1997) Langzeitergebnisse der Pars-plana-Vitrektomie bei ERU. Pferdeheilkunde 13, 377-383

Wollanke B., Gerhards H. (2009) Equine rezidivierende Uveitis. Cont. Vet. Educ. 1, 1-14

Wollanke B., Gerhards H., Brem S., Kopp H., Meyer P. (1998) Intraokulare und Serumantikörpertiter gegen Leptospiren bei 150 wegen equiner rezidivierender Uveitis (ERU) vitrektomierten Pferden. Berl. Münch. Tierärztl. Wschr. 111, 134-139

Wollanke B., Gerhards H., Brem S., Meyer P., Kopp H. (2004) Ätiologie der equinen rezidivierenden Uveitis (ERU): Autoimmunkrankheit oder intraokulare Leptospireninfektion. Pferdeheilkunde 20, 327-340

Wollanke B., Gerhards H., Brem S., Wolf E., Kopp H., Meyer P. (2000) Zur Leptospirenätiologie der equinen rezidivierenden Uveitis (ERU): Ergebnisse der Untersuchungen von Serum-und Glaskörperproben. Tierärztl. Praxis 28, 153-158

Wollanke B., Rohrbach B. W., Gerhards H. (2001) Serum and vitreous humor antibody titers in and isolation of Leptospira interrogans from horses with recurrent uveitis. J. Am. Vet. Med. Assoc. $219,795-800$

Ye C., Yan W., McDonough P. L., McDonough S. P., Mohamed H., Divers T. J., Yang Z. (2014) Serodiagnosis of equine leptospirosis by enzyme-linked immunosorbent assay using four recombinant protein markers. Clin. Vaccine Immunol. 21, 478-483 
Yu Q., Liu K., Su L., Xia X., Xu X. (2014) Perfluorocarbon Liquid: Its Application in Vitreoretinal Surgery and Related Ocular Inflammation. Biomed Res. Intern. ID250323. doi: 10.1155/2014/250323

Zemel E., Loewenstein A., Lei B., Lazar M., Perlman I. (1995) Ocular pigmentation protects the rabbit retina from gentamicin-induced toxicity. Investig. Ophthalm. Visual Sci. 36, 1875-1884.

Erweiterte Zusammenfassung

Intraokularer Leptospirennachweis mittels PCR, MAT, ELISA und Kultur von Pferden mit equiner rezidivierender Uveitis (ERU) in verschiedenen Laboren

Die equine rezidivierende Uveitis (ERU) ist eine Augenerkrankung, die vor allem durch wiederkehrende Entzündungsschübe verschiedener Augenabschnitte und unterschiedlich langen, entzündungsfreien Phasen geprägt ist. Unterschiedliche ätologische Theorien werden bis heute diskutiert, doch am häufigsten wird die "klassiche ERU" mit einer intraokularen Leptospireninfektion in Verbindung gebracht. Die pars plana Vitrektomie ist eine der erfolgreichsten operativen Therapieoptionen der ERU und die Erfolgsrate im Sinne einer Rezidivfreiheit scheint in Augen mit nachweisbaren leptospiralen Antikörpern besser zu sein. Ziel dieser Studie war es den Einfluss unterschiedlicher Labore auf Untersuchungsergebnisse und Nachweisraten leptospiraler DNS und Antikörper identischer Glaskörperproben zu untersuchen. Darüber hinaus wurde der Einfluss unterschiedlicher Methoden, wie zum Beispiel der kulturellen Anzucht, auf die Nachweisrate evaluiert.

Glaskörperproben von 93 Augen mit ERU wurden von 78 Pferden verschiedener Rassen und verschiedenen Alters während der Vitrektomie entnommen, geteilt und an verschiedene Labore in Deutschland versandt (L1, L2 und L3). L1 führte eine Polymerasekettenreaktion (PCR) und einen Mikroagglutinationstest (MAT) durch, L2 führte eine PCR durch und L3 führte einen MAT, eine kulturelle Anzucht und einen Enzyme Linked Immunosorbent Assay (ELISA) durch. Die Höhe der Glaskörperverdünnung wurde anhand des Harnstoffverhältnisses zwischen 34 Serum und Glaskörperproben ermittelt. Außerdem wurde eine Verdünnungsreihe mit unverdünntem Glaskörpermaterial erstellt, welches aus zwei enukleierten und an ERU erkrankten Augen stammte und zur PCR und zum MAT im L1 versandt wurde.
Die Ergebnisse der PCR zeigten eine deutliche Übereinstimmung zwischen L1 und L2 (Kappa 0,95), 52 Proben waren gleichzeitig positiv und 31 Proben gleichzeitig negativ in beiden Laboren. Lediglich zwei Proben zeigten voneinander abweichende Resultate. Der MAT im L1 erbrachte in 51 \% und im L3 in 41\% der Glaskörperproben ein positives Ergebnis. Die Übereinstimmung der MATs in L1 und L3 war sowohl serovar-, als auch rasseabhängig. Der Kappa für Serovar Grippotyphosa war 0,67 und für Serovar Pomona 0,82 (Tab. 5). Der Kappa für Warmblutpferde betrug 0,56, wohingegen der Kappa für Islandpferde 0,91 betrug. Eine erfolgreiche Anzucht gelang in $16 \%$ der Glaskörperproben. Die Verdünnung der Glaskörperproben schwankte sich zwischen 1 und $2,1( \pm 1,68)$.

Zusammenfassend wurden 67 Glaskörperproben parallel in allen drei Laboren getestet. Wenigsten ein positives Ergebnis in einem der durchgeführten Tests erreichten 57\% (38), wohingegen $43 \%$ (29) in allen Tests ein negatives Ergebnis erzielten (PCR in L1 und L2, MAT in L1 und L3, Kultur in L3). Die schwankenden Übereinstimmungen des MATs zwischen Serovar Grippotyphosa und Serovar Pomona, sowie zwischen Warmblutpferden und Islandpferden in L1 und L3 könnten durch den Gebrauch unterschiedlicher Stämme identischer Serovare erklärt werden. Die Verdünnung der Glaskörperproben muss für die Interpretation dieser Studie berücksichtigt werden, jedoch zeigte die Verdünnungsreihe einen untergeordneten Einfluss von einer Verdünnung bis zu 1:3. Die starke Übereinstimmung der PCR-Ergebnisse in L1 und L2 deuten auf eine ähnliche Sensitivität beider PCR-Protokolle hin.

Die PCR zeigte eine starke Übereinstimmung zwischen L1 und $L 2$, wohingegen serovar- und rasseabhängige Unterschiede zwischen den Ergebnissen des MAT in L1 und L3 bestanden, die für die Interpretation solcher Ergebnisse berücksichtigt werden muss. Somit kann eine auf einer einzigen MAT-Untersuchung von Kammerwasser basierende Entscheidung gegen eine Vitrektomie auf Grundlage der vorliegenden Studie nicht empfohlen werden.

Schlüsselwörter: Leptospiren, ERU, Uveitis,/ PCR, MAT 7, Ophthalmologie 